\title{
PENGEMBANGAN PEMAHAMAN AS-SUNNAH SEBAGAI SUMBER AJARAN ISLAM
}

\section{Sutoyo, M.Ag.*}

\begin{abstract}
The second source of Islamic Law is as-Sunnah, because the first one is al-Qur'an which is considered still global. The global one needs explaination and interpretation. The Existence of as-Sunnah is really required in order that the moslems are able to understand and to implement wholistically. Although the existence of al-Sunnah in ulemas is debated, some agree while others disagree. Several ulemas even refuse al-Sunnah as the second Islamic Law Source (they don't follow al-Sunnah) with several arguments. However, majority, the ulemas accept and agree to place as-Sunnah as the second Islamic law source. From majority, ulemas agree to place as-Sunnah as the second Islamic Law Source is also different from the usage of it. Some use as-Sunnah wholistically and some use as-Sunnah which is evaluated valid. To understand and to give the meaning of as-Sunnah for ulemas of Muhadisinn and Ușūliyin. It is also different. Ulemas of Muhadisīn give the meaning of as-Sunnah and al-ḥadīs similar that which comes wholistically from the prophet as what he said, he did and the decision (taqrir) of the prophet before and after bi'tsah (to be assigned as the prophet). Whereas the ulemas of usuliyin differ al-Sunnah and al-hadis. According to them, if all of them comes from the prophet said, did, and taqrir. It is named as al-Sunnah, if it is what to be said only by the prophet or qauliyah, it is named as al-hadis.
\end{abstract}

Kata kunci: as-Sunnah, al-Hadīs, al-Khabar, al-Aśar

\section{PENDAHULUAN}

Sesuai dengan sunnatullah yang berlaku, pemikiran manusia selalu bergerak menuju kepada kesempurnaan. Manusia tidak akan bisa berhenti 
dari berpikir, sebab eksistensi manusia salah satunya ditentukan oleh aktivitas berpikir. Di antara berbagai produk berpikir manusia itu adalah upaya-upaya untuk menyingkirkan as-Sunnah sebagai bagian dari rujukan sumber hukum, yang ditandai dengan munculnya gerakan inkār as-Sunnah. Hal ini tentunya sangat memprihatinkan, mengingat as-Sunnah merupakan bagian yang sangat penting dalam kehidupan seorang Muslim.

Menghadapi kenyaatan di atas, tulisan ini akan mengeksplorasi lebih jauh tentang as-Sunnah guna memberikan pengembangan pemikiran baru untuk direalisasikan dalam kehidupan sehari-hari, dan sekaligus benteng terhadap faham inkär as-Sunnah di Indonesia saat ini. Yang akan dibahas di sini mencakup: pengertian as-Sunnah dan istilah lain yang terkait kedudukannya as-Sunnah al-Qur'an, penolakan terhadap kelompok inkār as-Sunnah sebagai sumber ajaran Islam.

\section{PENGERTIAN AL-SUNNAH DAN KEDUDUKANNYA DALAM AJARAN ISLAM}

Di samping perkataan as-Sunnah terdapat pula istilah al-ḥadìs, alkhabar dan al-aṡar, baik dari segi bahasa maupun pemakaiannya dan istilah syara'.

\section{Sunnah}

Pengertian Sunnah menurut bahasa adalah:

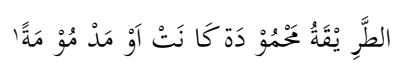

"Jalan yang terpuji dan atau yang tercela"

Dalam kaitan sunnah yang diartikan dengan الطريقة atau, Khālid bin 'Utbah al-Hāżi mengatakan:

$$
\text { فلا تجزعن من سيرة انت سرتا فاول راض سنة من يسيرها2 }
$$

"Janganlah kau halangi perbuatan yang telah kau lakukan, karena orang yang pertama menyenangi suatu perbuatan adalah orang yang melakukannya."

Dalam hadis Rasulullah saw. bersabda:

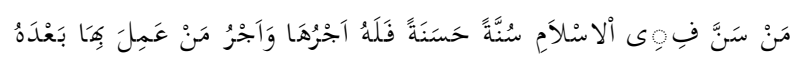




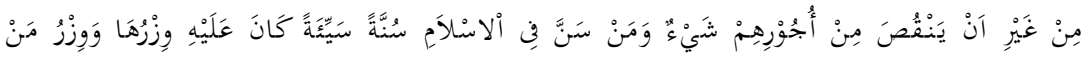

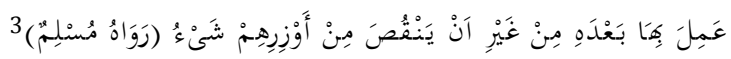

"Barang siapa melakukan sesuatu perbuatan yang baik, ia akan mendapatkan pahala dari perbuatannya itu dan pahala orang yang menirunya setelah dia, dengan tidak dikurangi pahalanya sedikitpun. Dan barang siapa melakukan perbuatan yang jelek, ia akan menanggung dosanya dan dosa orang-orang yang menirukannya, dengan tidak dikurangi dosanya sedikitpun." (HR.Muslim).

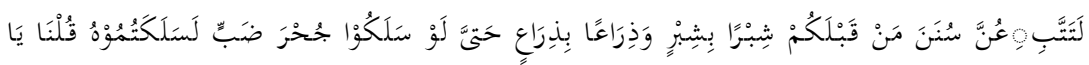

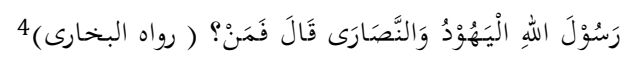

"Sungguh kalian akan mengikuti kebiasaan atau perbuatan orangorang sebelum kamu, sejengkal demi sejengkal dan sehasta demi sehasta, sehingga meskipun mereka memasuki lubang biawak, niscaya kamu akan mengikuti mereka. Kami (para sahabat) bertanya ya Rasulullah saw. apakah mereka itu yahudi dan nasrani?.Beliau menjawab Lantas Siapa lagi?." (HR.Bukhari).

Allah berfirman dal al-Qur'an:

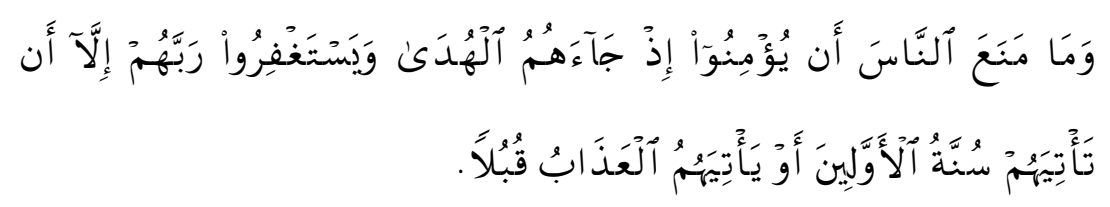

"Dan tidak ada sesuatupun yang menghalangi manusia dari beriman, ketika petunjuk Telah datang kepada mereka, dan dari memohon ampun kepada Tuhannya, kecuali (keinginan menanti) datangnya hukum (Allah yang Telah berlalu pada) umat-umat yang dahulu atau datangnya azab atas mereka dengan nyata."(QS. al-Kahfi/18: 55).

Sedangkan pengertian Sunnah menurut istilah di kalangan ulama' berbeda pendapat. Hal ini disebabkan karena perbedaan latar belakang, persepsi dan sudut pandang masing-masing terhadap diri Rasulullah saw. Mereka terkelompok menjadi tiga golongan. Pertama, ahli hadis, ahli usul, dan ahli fikih. 
Pengertian sunnah menurut ahli hadis adalah:

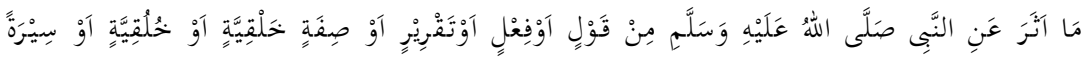

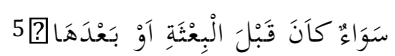

"Segala yang bersumber dari Nabi saw baik berupa perkataan, perbuatan, taqrīr, perangai, budi pekerti, perjalanan hidup baik sebelum diangkat menjadi rasul maupun sesudahnya".

Dengan definisi tersebut, para ahli hadis menyamakan antara sunnah dan hadis. Tampaknya para ahli hadis membawa makna sunnah ini kepada seluruh kebiasaan Nabi saw., baik yang melahirkan hukum syara' maupun tidak. Hal ini terlihat dari definisi yang diberikan mencakup tradisi Nabi sebelum masa diutusnya sebagai Rasul.

Pengertian sunnah menurut ulama Ușūliyyin adalah:

Semua yang bersumber dari nabi baik perkataan perbuatan dan taqrir Nabi yang dapat digunakan sebagai dalil hukum syara'. ${ }^{6}$

Pengertian sunnah menurut ulama fikih adalah:

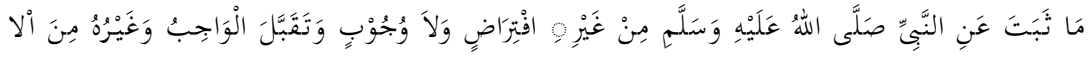

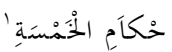

"Segala ketetapan yang berasal dari Nabi saw. selain yang difardukan dan diwajibkan dan termasuk hukum ( taklifi) yang lima."

\section{Al-H\{adī̇}

Hadis menurut bahasa berarti الجديد, yaitu sesuatu yang baru, menunjukkan sesuatu yang dekat dan waktu yang singkat, seperti perkataan: هو حديث العهد في لاسالم (Dia baru masuk/memeluk Islam).

Sedangkan menurut istilah seperti dalam pemakaian istilah asSunnah, pemakaian istilah al-hadis juga berbeda-beda sesuai dengan disiplin ilmu masing-masing. Ulama hadis menyamakan pengertian hadis dengan sunnah. Tetapi biasanya istilah al-hadiss dimaksudkan oleh mereka sebagai perbuatan, perkataan dan taqrïr Nabi saw. Sesudah bi'sah. Karenanya istilah as-sunnah lebih umum dari pada hadis. Ulama usul fikih mengartikan jika disebut hadis maka dimaksudkan sunnah qauliyyah (perkataan) saja. Sedangkan sunnah menurut mereka mencakup 
perkataan, perbuatan dan taqrīr Nabi saw. ${ }^{7}$

Menurut Muḥammad Maḥfūz 'Abd Allāh, hadis adalah:

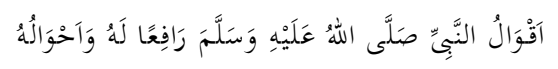

Segala perkataan Nabi, perbuatan dan ihwalnya.

Yang dimaksud ihwalnya yaitu segala yang diriwayatkan dari Nabi saw. yang berkaitan dengan himmah, karakterstik, sejarah kelahiran dan kebiasaan-kebiasaannya. ${ }^{8}$

\section{Al-Khabar}

Menurut ahli hadis, khabar dipandang sama dengan hadis. Oleh karena itu istilah ini mereka gunakan untuk hadis marfu', mauqū $f$ dan maqtu'. Dengan kata lain bahwa yang yang dimaksud dengan khabar ialah segala sesuatu yang dierima dari Nabi saw., sahabat atau tabi'in. Tetapi sebagian dari mereka membedakan, hadis ialah yang diterima dari Nabi saw. sedangkan khabar ialah yang menyangkut selain Nabi saw. ${ }^{9}$

\section{Al-Asāār}

Al-asāar berdasarkan bahasa sama pula artinya dengan khabar, hadis, dan sunnah. Adapun pengertian aśar menurut istilah terdapat perbedaan pendapat diantara para ulama. Jumhur ulama mengatakan bahwa atsar sama dengan khabar, yaitu sesuatu yang didasarkan kepada Nabi saw., sahabat, dan tabi'in. ${ }^{10}$

Dari uraian tersebut di atas, maka antara pengertian as-sunnah atau al-ḥadïs terdapat perbedaan isi akan tetapi tidak membawa kepada perbedaan prinsip. Ulama hadis yang melihat Nabi saw. sebagai figur pemimpin yang tingkah lakunya sangat ideal untuk menjadi suri tauladan, memberikan isi kepada as-sunnah atau hadis lebih luas. Tetapi ulama usul fikih, yang melihat as-sunnah sebagai landasan hukum disamping alQur'an, hanya memasukkan perkataan, perbuatan dan taqrïr Nabi saw. sesudah bi'sah untuk dijadikan sebagai dalil hukum syara'. Sementara istilah al-khabar dan al-aśar kurang populer digunakan untuk hadis atau sunnah tersebut di atas.

Berbicara kedudukan as-Sunnah di samping al-Qur'an sebagai sember ajaran Islam, maka al-Qur'an merupakan sumber pertama, sedangkan alsunnah menempati sumber kedua. Bahkan sulit dipisahkan antara al- 
Qur'an dan as-sunnah, karena keduanya adalah wahyu Allah swt., hanya yang pertama wahyun matluw dan yang kedua wahyun gairu matluw. Posisi as-sunnah seperti itu tidak hanya dijelaskan oleh Nabi saw., bahkan juga oleh Allah swt., antara lain:

QS. al- Fath/48\}: 10

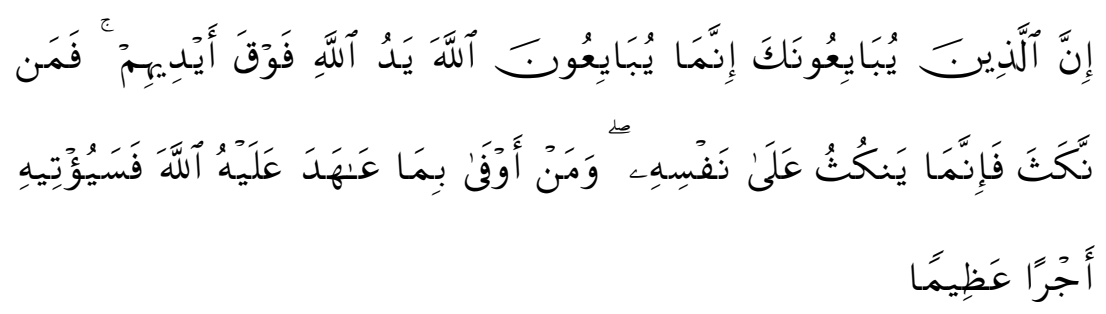

"Orang-orang yang berjanji setia kepada kamu sesungguhnya mereka berjanji setia kepada Allah tangan Allah di atas tangan mereka. Maka barangsiapa yang melanggar janjinya niscaya akibat ia melanggar janji itu akan menimpa dirinya sendiri dan barangsiapa menepati janjinya kepada Allah Maka Allah akan memberinya pahala yang besar."

QS. Al-Māidah/5: 92:

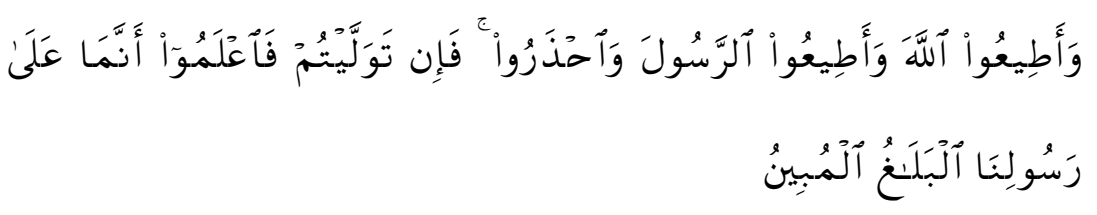

"Dan taatlah kamu kepada Allah dan taatlah kamu kepada Rasul(Nya) dan berhati-hatilah. jika kamu berpaling, maka Ketahuilah bahwa Sesungguhnya kewajiban Rasul kami, hanyalah menyampaikan (amanat Allah) dengan terang".

Demikian juga QS. an-Nisa/4: 65:

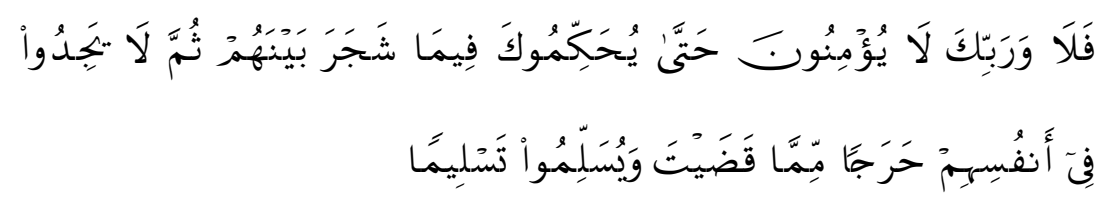

"Maka demi Tuhanmu, mereka (pada hakekatnya) tidak beriman hingga mereka menjadikan kamu hakim terhadap perkara yang 
mereka perselisihkan, Kemudian mereka tidak merasa dalam hati mereka sesuatu keberatan terhadap putusan yang kamu berikan, dan mereka menerima dengan sepenuhnya."

Mayoritas umat Islam sepakat meneriama al-sunnah sebagai sember ajaran Islam yang tak terpisahkan dari al-Qur'an. Tidak dipungkiri bahwa juga diantara umat Islam ada yang menolaknya.

Golongan yang menolak as-sunnah sebagai sumber ajaran Islam ada dua golongan:

a. Golongan yang menolak as-sunnah secara keseluruhan.

b. Golongan yang menolak hadis ahad saja.

Imām Syāfi'ī dalam kitab al-Umm menerangkan golongan yang menolak as-sunnah sebagai sumber ajaran Islam dengan panjang lebar, disertai dengan alasan-alasan mereka dan Imām Syāfi'î membantah pendapat mereka dengan alasan-alasan yang kuat dan menempatkan persoalannya secara proporsional. Ia membagai golongan yang menentang al-sunnah menjadi tiga golongan:

a. Golongan yang menolak as-sunnah secara keseluruhan, baik yang mutawatir maupun yang ahad.

b. Golongan yang menolak as-sunnah kecuali menerimanya jika ada persamaan dengan al-Qur'an.

c. Golongan yang menolak as-sunnah ahad.

Selain kitab al-Umm, Imām Syāfi'ì juga menyinggung para penolak hadis ini didalam kitab ar-Risālah dengan panjang lebar. Di dalam kitab arRisālah Imām Syāfi'i menerangkan dalil-dalil untuk membela al-sunnah terhadap tiga golongan tersebut.

Di samping itu mereka menolak al-sunnah karena al-sunnah itu żanni al-wurūd yang berbeda dengan al-Qur'an yang qațī al-wurūd. Sementara bila dilihat dari segi dalālah-nya atau maknanya baik al-Qur'an maupun assunnah ada yang qațî́ ad-dalālah (muḥkamat) tetapi ada juga yang zhanniy ad-dalalah.

\section{As-Sunnah sebagai Sumber Ajaran Islam}

Al-Qur'an mengandung pokok-pokok ajaran Islam secara global (mujmal), absolut (muțlāq) dan umum ('am) yang memerlukan rincian 
(tafșiil), pembatasan (taqyīd) dan pengkususan (takhșiș) atau secara umum dapat dikatakan bahwa al-Qur'an memerlukan bayān (keterangan lebih lanjut). Al-Qur'an dipandang dari sumber hukum merupakan asas atau dasar Islam. Ia mengatur dasar dan petunjuk hukum tentang hubungan Muslim dengan Tuhan dan hubungan seorang Muslim dengan sesama Muslim pada khususnya serta hubungan seorang Muslim dengan manusia pada umumnya. Sedangkan as-sunnah merupakan sumber hukum kedua, dan jika tidak terdapat pada keduanya barulah dilakukan ijtihad.

Sistematikanya adalah sebagai berikut:

1. Al-Qur'an ialah undang-undang dasar Islam bersumer dari Allah swt.

2. As-Sunnah; hadis ialah undang-undang Islam yang bersumber dari Rasulullah saw.

3. Ijtihad ialah peraturan Islam atau kaidah-kaidah hukum yang dirumuskan oleh orang-orang Muslim yang berilmu.

Dengan 6666 ayat atau ada yang menghitung 6236 ayat al-Qur'an menentukan asas kehidupan, mengatur prinsip-prinsip dan petunjuk kehidupan meliputi soal dunia dan akhirat.

Tiap-tiap hubungan memerlukan aturan. Kalau tidak akan terjadi salah hubungan. Dengan adanya aturan maka teraturlah hubungan tersebut. Islam mengatur hubungan manusia dengan Allah swt., hubungan manusia dengan manusia dan hubungan manusia dengan alam. Dasar aturannya ialah al-Qur'an. Di dalam keteraturan ada harmoni, keserasian dan keseimbangan. Demikian pula dalam aturan al-Qur'an terkandung harmoni.

Al-Qur'an menggariskan hukum dasar cara hidup seorang Muslim sebagai hamba Allah swt., individu, sebagai anggota sosial dan komunitas Muslim. Melalui hukum dasar itu diaturlah, dikendalikan dan diarahkan cara berpikir (rasio dan rasa) cara mengatur kemauan dan cara berbuat seorang Muslim sebagai individu dan sebagai anggota masyarakat.

Al-Qur'an memerlukan as-sunnah untuk menjelaskan, menafsirkan, mengulas dan melaksanakannya. Jadi, al-Qur'an lazimnya bersifat dasar dan umum. Ketika al-Qur'an memerintahkan salat, puasa, zakat, haji, taqwa dan beramal shalih, bagaimana melaksanakannya syarat-syarat dan rukun-rukun dan lain-lainnya tidak diuraikan dalam al-Qur'an. Oleh karena 
itu al-Qur'an memerlukan al-sunnah untuk menjelaskan, menafsirkan, mengulas, merinci dan, melaksanakannya dalam berbagai bentuk bayān.

Tugas dan fungsi al-Qur'an dalam semantik hukum Islam adalah alsunnah. Melalui as-sunnah, al-Qur'an diwujudkan dalam kehidupan yang nyata. Nabi Muhammad saw. dengan sunnahnya memberikan contoh yang kongkrit, bagaimana melaksanakan al-Qur'an dalam kehidupan. Oleh karena itu as-sunnah sangat penting kedudukannya didalam Islam sebagai sumber hukum Islam kedua setelah al-Qur'an. Di samping itu memahami memahami sirah nabawiyah sangatlah penting untuk memahami Islam secara utuh, karena hakikat Islam secara keseluruhan menjelma dalam kehidupan Nabi Muhammad saw.

Berbicara tentang fungsi Rasulullah saw., beliau tidak hanya sekedar menyampaikan wahyu Allah swt. kepada umat manusia, tetapi juga beliau memberi petunjuk bagaimana melaksanakan wahyu itu dalam kehidupan riil sehari-hari. Beliau memberi contoh bagaimana mewujudkan wahyu itu pada diri manusia. Karena itu Rasul mestilah manusia. Perubahan dan perbaikan manusia hanya mungkin dilakukan dan diberikan contoh oleh manusia itu sendiri. Kalau tidak, ia akan jauh dari realita dan fakta yang kongkrit.

Malaikat adalah juga utusan Allah swt., mengapa tidak mereka saja yang diangkat menjadi Nabi dan Rasul. Tugas Malaikat menyampaikan wahyu kepada manusia terpilih, manusia sempurna, yaitu yang diangkat Allah swt. sebagai Rasul-Nya. Malaikat adalah jenis mahluk yang berbeda debgan manusia, dia tidak bisa menjadi contoh bagai manusia, Rasulullah saw. sebagai manusia, Rasulullah saw. sebagai manusia yang sempurna, memungkinkan untuk menjadi suri tauladan bagi jenis manusia untuk kesempurnaan. Itulah makna al-Isrā' ayat 95 yang berbunyi:

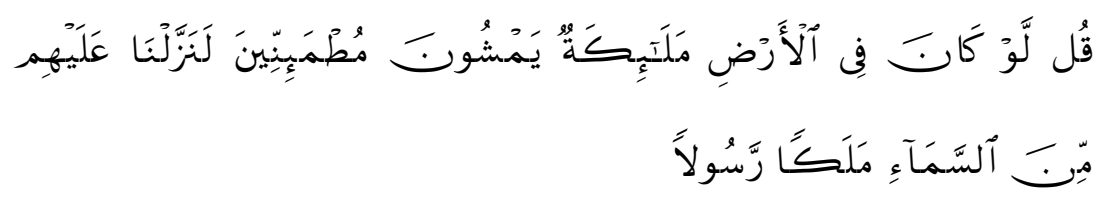

Katakanlah: "Kalau seandainya ada malaikat-malaikat yang berjalan-jalan sebagai penghuni di bumi, niscaya kami turunkan dari langit kepada mereka seorang malaikat menjadi Rasul"..

Bahwa Allah swt. tidak mengutus Malaikat sebagai Rasul tapi manusia 
yang kongkrit dari daging dan darah, yang makan dan minum serta suatu saat akan mati.

Tugas Rasul adalah mengadakan reformasi kehidupan manusia. Beliau mencontohkan sendiri dalam bentuk laku perbuatan, bagaimana reformasi itu. Beliau tidak hanya menyampaikan ilmunya, tetapi juga memperlihatkan bagaimana amalnya disamping berbentuk ucapan dan taqrir. Oleh karena itu ada sunnah quliyah, fi'liyah dan taqrïiyah.

Kalau Tuhan sendiri muncul di dunia sebagai manusia (inkarnāsi) memberikan reformasi kepada masyarakat, adalah contoh-contoh yang diamalkan-Nya itu tidak realistis. Allah Maha Sempurna dan tidak sama dengan mahluk. Tetapi manusia sebagai Rasul dengan segala nafsu dan segala kelemahannya sebagai manusia akan dapat memberikan teladan yang relaistis.

Sebagaimana Allah swt. menyediakan bahan-bahan material seperti bahan makanan, perumahan, obat-obatan dan lain-lain untuk memelihara jasmani manusia, demikian pula Allah swt. menyediakan bahanbahan rahani itu dalam bentuk ajaran. Yang diturunkan Allah swt. sebagai wahyu kepada Nabi dan Rasul melalui Malaikat Jibril. Pada ruang dan waktu tertentu Allah swt. mengangkat Nabi dan Rasul, untuk mengubah dan memperbaiki rohani manusia di ruang dan waktu tertentu. Rohani menggerakkan jasmani, dari jasmani lahirlah laku perbuatan yang kongkrit, yang mengisi kehidupan. Demikian untuk perbaikan dan perubahan kehidupan manusia diruang dan waktu tertentu. Allah swt. mengutus Nabi dan Rasul tertentu.

Demikianlah dalam perjalanan umat manusia Allah swt. Mengutus Nabi demi Nabi hingga 120.000 orang dan mengutus Rasul demi Rasul hingga 313 orang Rasul. Karena itu sejarah memberitakan terjadinya perubahan atau perbaikan pada bangsa tertentu dalam kurun dan ruang tertentu. Nabi Muhammad saw. lahir 570 Masehi di Makkah dan wafat 623 Masehi di Madinah. Al-Qur'an yang dibawa oleh Nabi Muhammad saw. menyatakan bahwa beliau adalah utusan Allah swt. terakhir sebagaimana firman Allah swt. dalam surat Sabā'/34: 28 


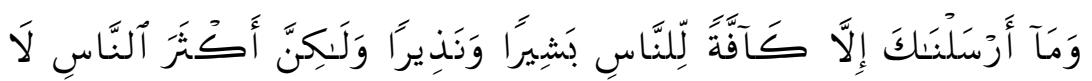

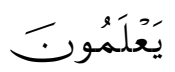

Dan Kami tidak mengutus kamu, melainkan kepada umat manusia seluruhnya sebagai pembawa berita gembira dan sebagai pemberi peringatan, tetapi kebanyakan manusia tiada Mengetahui.

Al-Qur'an surat al-A'rāf /7: 158

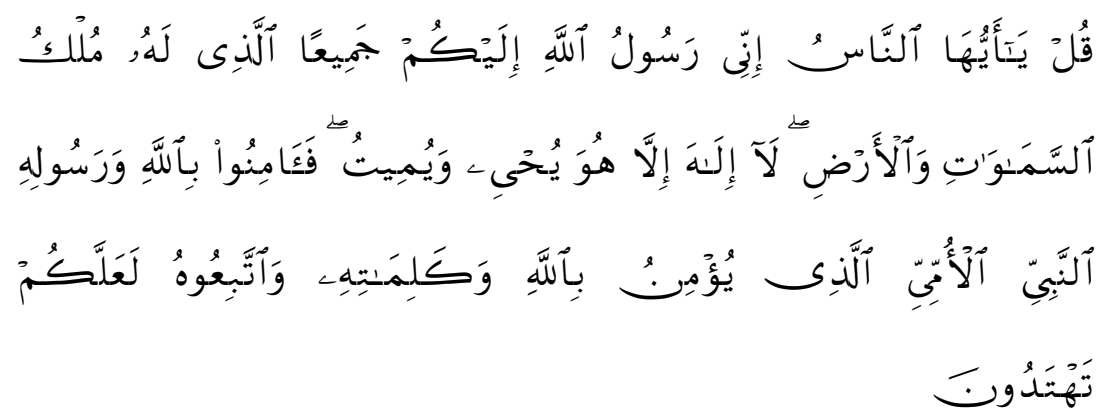

Katakanlah: "Hai manusia, sesungguhnya Aku adalah utusan Allah kepadamu semua, yaitu Allah yang mempunyai kerajaan langit dan bumi; tidak ada Tuhan (yang berhak disembah) selain Dia, yang menghidupkan dan mematikan, maka berimanlah kamu kepada Allah dan Rasul-Nya, nabi yang ummi yang beriman kepada Allah dan kepada kalimat-kalimat-Nya (kitab-kitab-Nya) dan ikutilah Dia, supaya kamu mendapat petunjuk".

Al-Qur'an surat al-Anbiyā'/21: 107

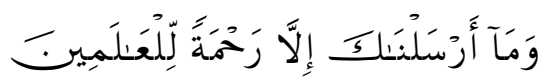

Dan tiadalah Kami mengutus kamu, melainkan untuk (menjadi) rahmat bagi semesta alam.

Di samping itu al-Qur'an berulang-ulang menyebut bahwa nama Muhammad saw. adalah untuk semua bangsa, untuk umat manusia, untuk seluruh alam.

Golongan yang menolak hadis sebagai sumber hukum Islam secara 
keseluruhan menggunakan alasan-alasan sebagai berikut:

1. Al-Qur'an adalah kitab suci yang berbahasa arab yang sudah tentu menggunakan gaya bahasa yang biasa digunakan oleh bangsa Arab. Kalau seseorang telah mengenal gaya bahasa arab, maka akan mampu memahami al-Qur'an tanpa memerlukan penjelasan hadis atau sunnah dan penjelasan lain.

2. Al-Qur'an sendiri telah menyatakan bahwa ia telah mencakup segala hal yang dibutuhkan oleh manusia mengenai segala aspek kehidupannya sebagaimana firman Allah swt. surat an-Nahl/: 89

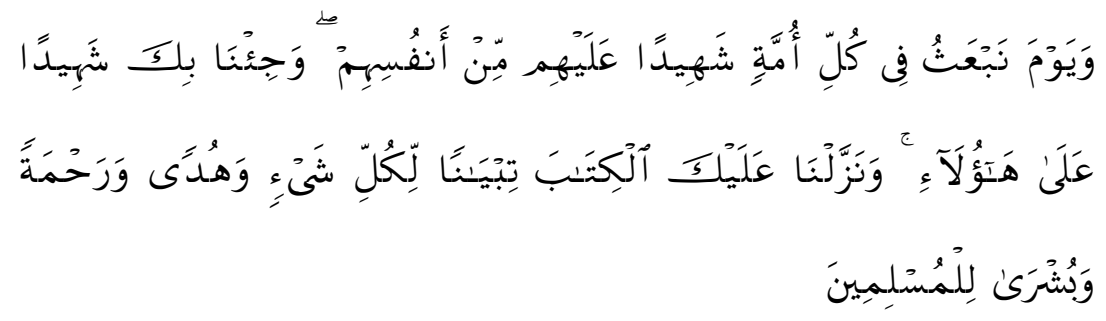

"(Dan ingatlah) akan hari (ketika) kami bangkitkan pada tiap-tiap umat seorang saksi atas mereka dari mereka sendiri dan kami datangkan kamu (Muhammad) menjadi saksi atas seluruh umat manusia. dan kami turunkan kepadamu al-Kitab (al-Qur'an) untuk menjelaskan segala sesuatu dan petunjuk serta rahmat dan kabar gembira bagi orang-orang yang berserah diri."

Dan juga surat al-An'am ayat 36:

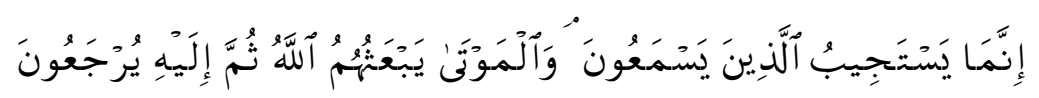

"Hanya mereka yang mendengar sajalah yang mematuhi (seruan Allah), dan orang-orang yang mati (hatinya), akan dibangkitkan oleh Allah, Kemudian kepadaNyalah mereka dikembalikan".

Dan juga berdasarkan hadis Nabi saw.:

$$
\text { مكا أتا كم عنى فاعرضوه على كتاب الله فان وافق كتاب الله فأناقلته وان خالف تاب الله فلم اقله أنا }
$$

Apa-apa yang sampai kepadamu dari saya, maka cocokkanlah dengan kitab Allah (al-Qur'an). Jika sesuai dengan kitab Allah 
maka aku telah mengatakannya. Bagaimanakah aku dapat berbeda dengan kitab Allah sedangkan dengannya Allah memberi petunjuk kepadaku.

Imām Syāfi'ì menolak golongan yang menolak hadis sebagai sumber hukum Islam secara keseluruhan dengan menggunakan argumentasi berikut. Menurut kenyataan bahwa umat Islam dalam mengamalkan firman Allah swt. tidak dapat lepas dari penjelasan atau keterangan dari hadis. Sebab banyak firman Allah swt. yang bersifat mujmal, muțlāq, dan bersifat umum yang membutuhkan kepada bayān baik berupa rincian, taqyīd dan taqșịs. Untuk itu, Nabi saw. yang diberi tugas dan wewenang untuk memberikan bayān, sebagamana firman Allah swt. surat anNaḥl/16: 44

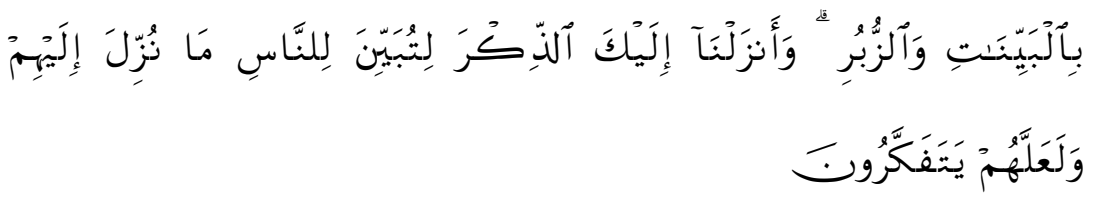

Keterangan-keterangan (mukjizat) dan kitab-kitab, dan Kami turunkan kepadamu al-Quran, agar kamu menerangkan pada umat manusia apa yang telah diturunkan kepada mereka dan supaya mereka memikirkan.

Yang dimaksud dengan surat an-Nahl tersebut di atas ialah sesuatu yang diperlukan oleh manusia seutuhnya secara global dan terinci. Penjelasan lebih lanjut ditugaskan kepada Rasulullah saw. Sedangkan surat al-An'ām: 38 ialah segala sesuatu yang terjadi di dunia ini, terutama mengenai umur seseorang dan rizkinya, sudah termaktub dan sudah ditentukan di dalam al-Lauh al-Mahfüz, dan bukan al-Qur'an. Pengertian ini diambil dari rangkaian kalimat sebelumnya dari ayat tersebut:

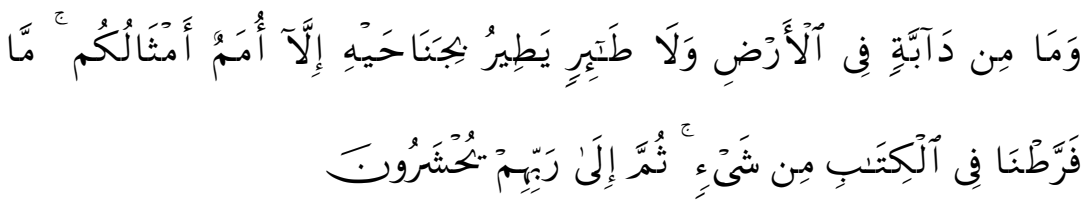

"Dan tiadalah binatang-binatang yang ada di bumi dan burungburung yang terbang dengan kedua sayapnya, melainkan umat (juga) seperti kamu. Tiadalah Kami alpakan sesuatupun dalam Al- 
Kitab. Kemudian kepada Tuhanlah mereka dihimpunkan."

Bahwa yang dianggap hadis oleh mereka sebagaimana tersebut pada butir tiga di atas, menurut penelitian ahli-ahli hadis ternyata hadis maudu' (palsu).

Menurut Imām Syāfi'ī golongan yang menolak hadis dapat menimbulkan konsekuensi yang berat sekali, karena kalau kita mengikuti pendapat mereka, maka kita tidak akan mengerti cara-cara mengerjakan salat, puasa, zakat dan haji yang dalam al-Qur'an disebutkan secara global saja. Sedangkan kita dapat mengamalkan ibadah tersebut berdasarkan penjelasan dari Nabi saw. atau hadis.

Allah swt. telah memerintahkan kita beriman kepada Rasul-Nya. beriman kepada Rasul itu wajib taat kepadanya, baik terhadap ucapan, perbuatan maupun taqrīr-nya. Dengan demikian wajib bagi umat Islam beriman kepada hadis sebagai hukum Islam sebagaimana firman Allah swt. surat al-A'rāf/7: 158:

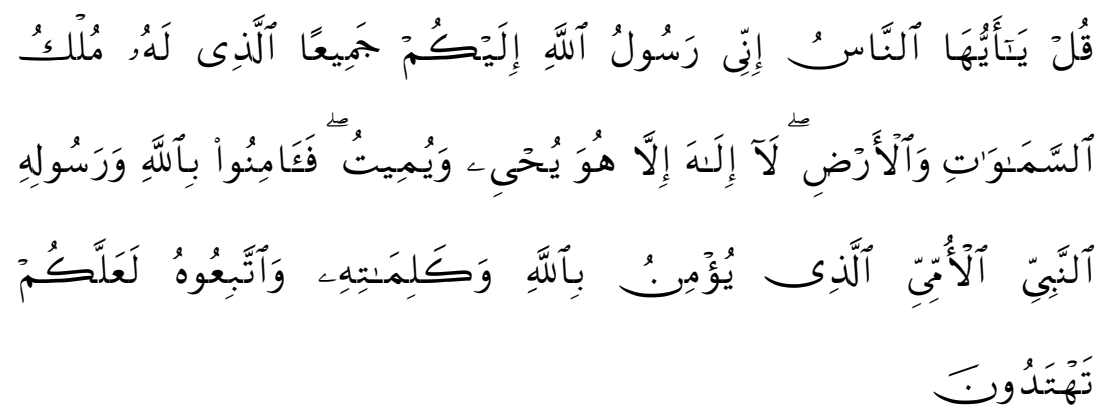

"Katakanlah: "Hai manusia sesungguhnya aku adalah utusan Allah kepadamu semua, yaitu Allah yang mempunyai kerajaan langit dan bumi; tidak ada Tuhan (yang berhak disembah) selain Dia, yang menghidupkan dan mematikan, maka berimanlah kamu kepada Allah dan Rasul-Nya, nabi yang ummi yang beriman kepada Allah dan kepada kalimat-kalimat-Nya (kitab-kitab-Nya) dan ikutilah Dia, supaya kamu mendapat petunjuk".

Dan juga surat an-Nūr/24: 62 


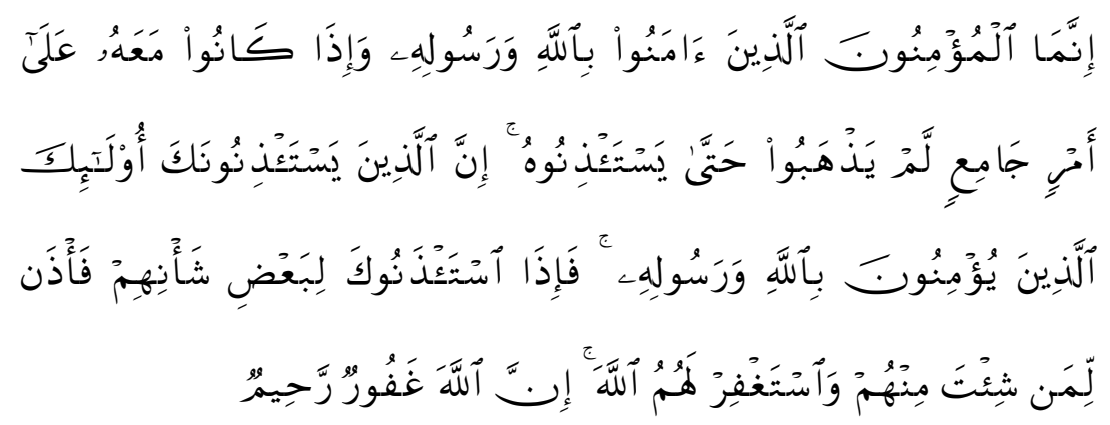

"Sesungguhnya yang sebenar-benar orang mukmin ialah orangorang yang beriman kepada Allah dan Rasul-Nya, dan apabila mereka berada bersama-sama Rasulullah saw. dalam sesuatu urusan yang memerlukan pertemuan, mereka tidak meninggalkan (Rasulullah saw.) sebelum meminta izin kepadanya. Sesungguhnya orang-orang yang meminta izin kepadamu (Muhammad) mereka itulah orang-orang yang beriman kepada Allah dan Rasul-Nya, maka apabila mereka meminta izin kepadamu karena sesuatu keperluan, berilah izin kepada siapa yang kamu kehendaki di antara mereka, dan mohonkanlah ampunan untuk mereka kepada Allah. Sesungguhnya Allah Maha Pengampun lagi Maha Penyayang."

Allah swt. tidak akan menjadikan ajakan Rasul untuk mengerjakan sesuatu seperti ajakan seseorang kepada orang lain diantara kita. Juga Allah swt. tidak menjadikan orang yang menentang Rasul seperti menentang orang lain, karena orang yang menentang Rasul diancam oleh Allah swt. akan mendapatkan bencana dan siksaan yang berat. Dengan demikian segala keputusan Rasul itu merupakan pedoman untuk diamalkan. Firman Allah swt. surat an-Nūr/24: 63 menjelaskan:

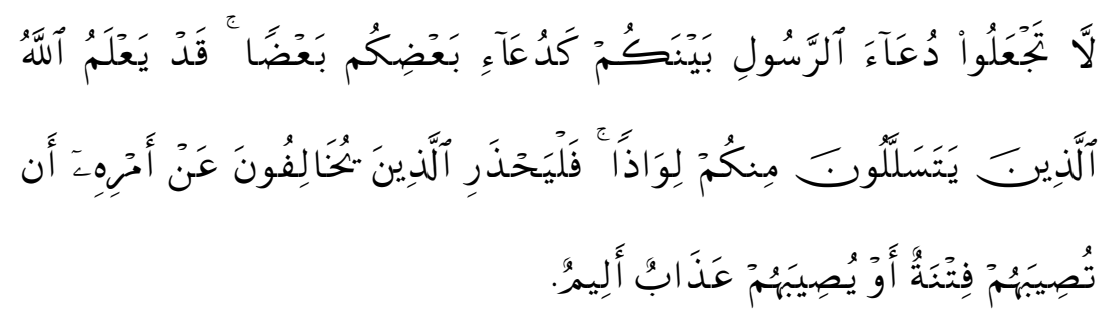

"Janganlah kamu jadikan panggilan Rasul diantara kamu seperti 
panggilan sebahagian kamu kepada sebahagian (yang lain). Sesungguhnya Allah telah mengetahui orang-orang yang berangsurangsur pergi di antara kamu dengan berlindung (kepada kawannya), maka hendaklah orang-orang yang menyalahi perintah-Nya takut akan ditimpa cobaan atau ditimpa azab yang pedih".

Allah telah memerintahkan kepada Nabi supaya menyampaikan risalah-Nya menjalankan syari'at-Nya dan mengikuti wahyu-Nya sebagaimana tercantum dalam surat al-Māiidah/5: 67

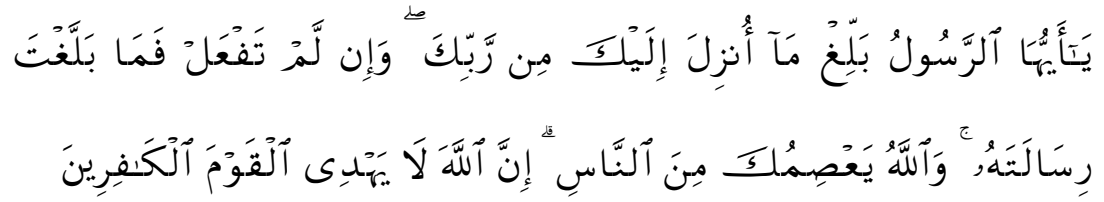

"Hai rasul, sampaikanlah apa yang diturunkan kepadamu dari Tuhanmu. dan jika tidak kamu kerjakan (apa yang diperintahkan itu, berarti) kamu tidak menyampaikan amanat-Nya. Allah memelihara kamu dari (gangguan) manusia. Sesungguhnya Allah tidak memberi petunjuk kepada orang-orang yang kafir."

Adapun golongan yang menolak hadis ahad sebsagai hujjah karena hadis ahad tingkatannya zannī al-Wurīd, maka pada hakikatnya penolakan itu masih bersifat sementara, sebelum diadakan penelitian terhadap hadis tersebut dari segi sanad maupun matan.

Setelah ditelitikualitas hadis ahad tersebut dapat dibedakan mana hadis yang dapat diterima sebagai hujjah dan mana yang tidak. Dari segi kualitas hadis ahad dibagi tiga yaitu șaḥīh, hasan dan da'if. Di bawah ini diuraikan secara singkat tentang hadis ahad sebagai berikut:

Menurut istilah hadis șahīh adalah hadis yang sanadnya bersambung diriwayatkan oleh orang-orang yang adil, dan dhabith serta tidak terdapat didalamnya suatu kejanggalan (syadż) dan cacat.

Berdasarkan hadis ini, maka hadis-hadis munqați' mu'ḍal, mu'allaq, mudallas dan mursāl tidaklah termasuk hadis șaḥihh. Karena hadis-hadis tersebut tidak bersambung sanad-nya. Sedangkan hadis musnad dan muttașil. Walaupun sanadnya bersambung, tetapi karena kualitas riwayat dan kandungan matan masih harus diteliti, maka belumlah dapat dipastikan sebagai hadis șaḥih. Demikian pula hadis masyhūr,' azīz dan 
garīb.

Ulama hadis telah membagi hadis șahīh menjadi dua yaitu șahīh li żātihi yaitu sahih karena keadaan dirinya sendiri telah memenuhi syarat lima hadis sahih sebagaimana telah dikemukakan diatas. Dan yang kedua adalah șậih li gairihi yaitu sahih karena adanya hadis lain yang mendukung. Misalnya ada hadis yang berkualitas hasan li żātihi, lalu ada dalil lain yang menguatkannya. Contoh ada dua buah hadis yang semakna sama-sama berkualitas ḥasan li żätihi atau sebuah hadis hasan li żātihi kemudian ada yang bersesuaian benar dengannya, maka kualitas hadis itu meningkat menjadi hadis șạ̣ih li gairihi.

Menurut istilah hadis hasan adalah hadis yang sanadnya bersambung diriwayatkan oleh orang yang adil tetapi kurang sedikit ke-dabiț-annya tidak dapat didalamnya satu kejanggalan (syadż) dan tidak juga terdapat kecacatan. Selanjutnya ulama hadis telah membagi hadis hasan kepada dua macam yaitu hadïs hasan li żātihi sebagaimana yang telah diterngkan diatas, dan hadis hasan li gairihi yaitu hadis yang sanadnya dan rawi yang tidak diketahui keahliannya, tetapi dia bukanlah orang yang terlalu banyak kesalahannya atau tertuduh dusta dalam meriwayatkan hadis, kemudian ada matan dengan sanad yang lain yang sesuai dengannya. Dengan pengertian ini maka hasan li ghairihi sesungguhnya pada dasarnya adalah da'if. Kemudian ada petunjuk lain yang menolongnya, yang disebut dengan asy-syahid dan al-Mutabi' yang jalur perawinya lebih kuat, sehingga meningkat menjadi hasan. Sekiranya tidak ada penolong, atau sama statusnya maka tetap da'if.

Adapun pengertian hadis da'if menurut ulama hadis adalah hadis yang tidak memiliki salah satu syarat atau lebih dari syarat-syarat hadis șahīh dan hadis hasan. Oleh karena itu, suatu hadis pada asalnya dianggap da'if, selama belum dapat dibuktikan ke-șahīhan-nya atau ke-hasan-annya. Para ulama hadis dalam membahas tingkatan kualitas hadis, umumnya telah berusaha untuk menjelaskan letak ke-ḍ'ifan-nya, bila hadis yang bersangkutan dinyatakan da'if. Sebab dengan penjelasan itu dapat diketahui tentang berat ringannya kekurangan atau cacat yang dimiliki oleh hadis yang bersangkutan, bahkan dimungkinkan untuk diketahui dapat tidaknya hadis itu ditingkatkan kualitasnya menjadi hasan li gairihi. Dengan melihat pengertian hadis da'if di atas, maka dapatlah dipahami bahwa pengertian 
hadis da'if tidaklah sesederhana pembagian hadis shahih dan hadis hasan karena alternatif persyaratan yang tidak dipenuhi sebagai hadis sahih dan hadis hasan, sangat bervariasi sehingga macam-macam hadis da'if itu tidak sedikit jumlahnya.

Terhadap berbagai macam hadis di atas (yang șaḥihh, hasan dan da'iff), ulama telah membagi-baginya lagi jika dilihat dari segi diterima dan tidaknya sebagai dalil. Hadis șaḥih dan hasan, dinyatakan sebagai hadis yang maqbūl, swdang yang d̆ da'if dinyatakan berstatus mardūd. Kemudian hadis yang berstatus maqbūl dipilih lagi kepada dua macam, yaitu hadis ma'mul bih dan yang gairu ma'mul bih. Dengan untuk menolak sebagai sumber ajaran hukum Islam, demikian maka hadis ahad yang tertinggi tingkatan kualitasnya adalah hadis yang ma'mul bih.

\section{KESIMPULAN}

Berdasarkan uraian-uraian di atas baik secara filosofis ('aqly) maupun secara naqly maka kedudukan as-Sunnah terhadap al-Qur'an sebagai bayān tafṣil, bayān taqyīd, bayān takhșiș dan seterusnya yang merupakan penjelasan dan penafsiran untuk al-Qur'an.

Hadis Nabi saw. pada umumnya diriwayatkan secara żannī. Jumlah hadis yang diriwayatkan secara qați î terlalu sedikit bila dibandingkan dengan yang diriwayatkan secara zannī. Zannī al-wurūd bagi periwayatan hadis bersifat sementara dan titik perhatian penelitian ulama hadis tertuju pada sanad (termasuk rawi) dan matan hadis. Berangkat dari kedua masalah pokok ini, maka ulama hadis telah membagi-bagi hadis ke berbagai macam dan banyak variasinya, mengingat bentuk dan keadaan sanad serta matan itu sendiri.

Pada hakikatnya, pembagian hadis yang bermacam-nacam itu tidak terlepas dari tujuan utama penelitian hadis, yakni untuk memilah-milah mana hadis yang benar-benar dapat dipertanggung jawabkan dan mana yang tidak. Mengingat keragaman bentuk dan keadaan sanad serta matan tersebut, maka tingkat kualitas hadis terbagi pada tiga kemungkinan yaitu șạihh, hasan dan da'if. Pembagian ini mencakup semua hadis yang berstatus maqbūl dan mardūd, khususnya yang maqbul diantaranya ada yang ma'mul bih merupakan hadis yang tertinggi tingkatannya disamping hadis mutawattir. Dengan demikian dilihat dari aspek epistimologi, yakni mengenai metode penelitian sanad dan matan yang cermat dan baku, 
maka tidak ada alasan. Untuk mencapai kebahagiaan dunia akhirat atau lahir dan batin maka al-Qur'an dan hadis merupakan dua sumber yang saling melengkapi dan integral, tak terpisahkan satu sama lain.

\section{Catatan akhir}

*Sutoyo, M.Ag adalah Dosen STAIN Ponorogo.

${ }^{1}$ Muștafāa as-Sibā'i, as-Sunnah wa Makānatuhā fi at-Tasyrī' al-Islāmi (Kairo : Dār as-Salām, 1998), h. 57.

2Muhammad Ajjāj al-Khāțib, as-Sunnah Qabla at-Tadwin (Beirut: Dār al-Fikr, 1997), h. 17.

${ }^{3} \mathrm{Abū}$ al-H\{usain Muslim bin al-H \{ajjāj al-Qusyairī an-Naisabūrī (Imām Muslim), Șaḥīh Muslim Syaraḥ an-Nawāwī, juz II, (Kairo: Maṭba'ah alMișriyah, 1349), h. 705.

${ }^{4}$ Imām Bukhārī, Sạhīh Bukhārī (Beirut: Dār al-Fikr, 1994), h. 234.

${ }^{5}$ Mușțafā as-Sibā’i, as-Sunnah, 57.

${ }^{6}$ Muhammad Ajjāj al-Khāṭib, as-Sunnah, h. 27.

${ }^{7}$ Mușțafā as-Sibā’i, as-Sunnah, 58.

${ }^{8}$ Said Agil Husen al-Munawar, Dimensi-dimensi Kehidupan Dalam Perspektif Islam (Malang: Pascasarjana Unisma, 2001), h. 16.

${ }^{9}$ Muḥammad Mahfūz bin Abdillāh atl-Tirmisī, Manhāj, awī an-Naẓar (Jeddah: al-Haramain,1974), h. 8.

${ }^{10}$ Said Agil Husen al-Munawar, Dimensi-dimensi Kehidupan, h. 16.

${ }^{11}$ Mudasir, Ilmu Hadis (Bandung: Pustaka Seta, 2007), h. 32.

\section{DAFTAR PUSTAKA}

Imām Bukhārī, Șaḥīh Bukhārī (Beirut: Dār al-Fikr, 1994).

Imām Muslim, Abū al-H\{usain Muslim bin al-Hajjāj al-Qusyairī anNaisabūrī, Șahīh Muslim Syaraḥ an-Nawāwī, juz II, (Kairo: Maṭba'ah al-Mișriyah, 1349).

Khāṭib, Muhammad Ajjāj, as-Sunnah Qabla at-Tadwīn (Beirut: Dār al-Fikr, 1997).

Mudasir, Ilmu Hadis (Bandung: Pustaka Seta, 2007). 
Munawar, Said Agil Husen, Dimensi-dimensi Kehidupan Dalam Perspektif Islam (Malang: Pascasarjana Unisma, 2001).

Sibāì, Mușțafā, as-Sunnah wa Makānatuhā fi at-Tasyrì' al-Islāmi (Kairo : Dār as-Salām, 1998).

Tirmisī, Muḥammad Mahfūẓ bin Abdillāh, Manhāj, awī an-Nazar (Jeddah: al-Haramain, tth). 